\title{
Гибридные световоды для компенсации дисперсии в области 1 мкм
}

\author{
С.С. Алешкина ${ }^{1, *}$, М.В. Яшков ${ }^{2}$, М.Ю. Салганский ${ }^{2}$, Д.С. Липатов ${ }^{2}$, А.К. Сенаторов ${ }^{1}$, \\ Л.Д. Исхакова ${ }^{1}$, М.М. Бубнов ${ }^{1}$, А.Н. Гурьянов ${ }^{2}$, М.Е. Лихачев ${ }^{1}$ \\ ${ }^{1}$ Научный иентр волоконной оптики РАН \\ ${ }^{2}$ Институт химии высокочистых веществ РАН \\ *E-mail: $\underline{\text { svalesh@fo.gpi.ru }}$
}

DOI:10.31868/RFL2018.144-145

Созданию специальных волоконных световодов с аномальной в области 1 мкм дисперсией посвящено большое число работ. Однако с практической точки зрения большинство из них обладают недостатками (маломодовый режим работы, высокие потери, высокая нелинейность и т.п.). В связи с этим поиск новых конструкций волоконных световодов с аномальной в области 1 мкм дисперсией остается крайне важной задачей.

Одним из наиболее перспективных типов волоконных световодов с аномальной дисперсией на длине волны около 1 мкм является гибридный световод. Гибридные световоды - это волоконные структуры с показателем преломления сердцевины выше уровня кварцевого стекла, окруженные одним или двумя оптически более плотными кольцевыми слоями, за которыми следует слой с пониженным относительно уровня кварца показателем преломления [1,2]. Своему происхождению такие структуры обязаны конструкции брэгговского световода [3], где достижение аномальной дисперсии моды сердцевины осуществлялось на границе с запрещенной зоной, а сама мода имела достаточно высокие потери на распространение вследствие механизма формирования и удержания моды (когерентное отражение от оптически более плотных кольцевых слоев). Эти существенные для волноведущих структур недостатки были устранены в структуре гибридного световода. В данном случае рабочей является мода $\mathrm{LP}_{0, \mathrm{i}+1}$, где $\mathrm{i}-$ количество кольцевых слоев с высоким показателем преломления, которую мы называем гибридной. Вследствие того, что механизмом удержания моды в случае гибридного световода является полное внутреннее отражение, уровень потерь на распространение гибридной моды ограничен фундаментальными потерями. Локализация гибридной моды в сердцевине обусловлена когерентным френелевским отражением от кольцевых слоев с высоким показателем преломления, окружающими сердцевину. По этой причине гибридная мода обладает рядом свойств, схожих со свойствами брэгговской моды. Так лишь гибридная мода локализована в сердцевине световода, а все остальные моды (включая фундаментальную) локализованы в кольцевых слоях. Более того, такая мода может иметь аномальную в области 1 мкм дисперсию. Величина и знак наклона дисперсии гибридной моды могут варьироваться в зависимости от параметров сердцевины и оптически более плотных кольцевых слоев [4]. Дисперсия в области 1,064 мкм может достигать величины более 100 псек/(нм км). Кроме того, возбуждение этой моды может быть осуществлено путем обычной сварки со световодом стандартного типа с согласующимся размером модового пятна. При этом величина диаметра поля моды гибридного световода, в отличие от большинства существующих конструкций световодов с аномальной в области 1 мкм дисперсией, может варьироваться в зависимости от поставленной задачи в диапазоне от нескольким микрон до 13 мкм и более [4]. 
Однако необходимо отметить, в силу того, что конструкция гибридного световода по сути является маломодовой, в данном случае может иметь место перекачка мощности между гибридной модой сердцевины и модами кольцевых слоев на резонансных длинах волн, что проявляется в появлении в спектре гибридного световода дополнительных интенсивных пиков поглощения [1]. Кроме того, возбуждение при сварке с обычным световодом небольшой доли мощности мод, локализованных в кольцевых слоях, препятствует установлению одноимпульсного режима генерации в лазерных схемах с синхронизацией мод. Вследствие этого, для подавления нежелательных мод световода и установления асимптотически одномодового режима распространения были предложены две методики. Первая основана на принципе поглощения нежелательных мод гибридного световода и состоит во внесении в положение минимума интенсивности рабочей моды сильно поглощающего слоя, который оказывает воздействие только на те моды, интенсивность которых отлична от нуля в области слоя [4]. Вторая методика состоит в селективном усилении рабочей моды световода. В этом случае центральная область сердцевины легируется активной добавкой (так как работа осуществляется в спектральном диапазоне около 1 мкм, в качестве активной добавки могут быть использованы ионы иттербия). Одномодовый режим распространения в этом случае достигается за счет различия перекрытия области легирования и распределения интенсивности полей мод световода.

Чтобы проверить применимость гибридного световода на практике, на основе конструкции гибридного световода с селективным подавлением мод была реализована схема задающего лазера, позволившая получить солитоны высшего порядка с длительностью импульса 700 фсек, энергией в импульсе 0,55 нДж и пиковой мощностью 800 Вт. Результаты по использованию гибридного световода с селективным усилением рабочей моды в схеме задающего источника будут доложены на конференции.

Работа выполнена при поддержке гранта РНФ 18-19-00687

\section{Литература}

[1] S. S. Aleshkina, M. E. Likhachev, et al., Opt. Express 21, 23838-23843 (2013)

[2] S. S. Aleshkina, M.E. Likhachev, et al, Proc. SPIE 9344, 934405 (2015)

[3] M.E. Likhachev, A.E.Levchenko, et al, in European Conference on Optical Communication 2007, Berlin, Germany, We7.1.2 (2007)

[4] S. S. Aleshkina, M. V. Yashkov, et al., in IEEE Journal of Selected Topics in Quantum Electronics 24, pp. 1-8 (2018)

[5] С. С. Алешкина, и др., Квантовая электроника, 46:8, 738-742 (2016) 